\title{
GREENHOUSE-GAS EMISSIONS FROM BIOFUEL USE IN ASIA
}

\author{
by \\ David G. Streets* and Stephanie T. Waldhoff \\ Decision and Information Sciences Division \\ Argonne National Laboratory \\ 9700 South Cass Avenue \\ Argonne, II 60439, U.S.A.
}

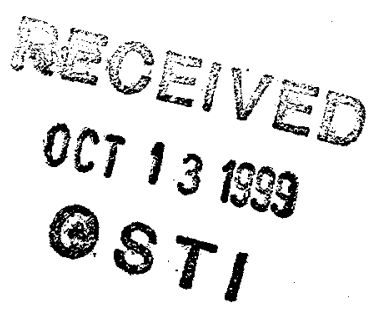

\begin{abstract}
The submitted manuscript has been created by the University of Chicago as Operator of Argonne National Laboratory ("Argonne") under Contract No. W-31-109-ENG-38 with the U.S. Department of Energy. The U.S. Government retains for itself, and others acting on its behalf, a paid-up, nonexclusive, irrevocable worldwide license in said article to reproduce, prepare derivative works. dis. tribute copies to the public. and perform pubticly and display publicly, by or on behalf of the Government.
\end{abstract}

to be presented at

Second International Symposium on Non- $\mathrm{CO}_{2}$ Greenhouse Gases

Noordwijkerhout, The Netherlands

September 8-10, 1999

Primary author to whom correspondence should be sent. Email: dstreets@anl.gov 


\section{DISCLAIMER}

This report was prepared as an account of work sponsored by an agency of the United States Government. Neither the United States Government nor any agency thereof, nor any of their employees, make any warranty, express or implied, or assumes any legal liability or responsibility for the accuracy, completeness, or usefulness of any information, apparatus, product, or process disclosed, or represents that its use would not infringe privately owned rights. Reference herein to any specific commercial product, process, or service by trade name, trademark, manufacturer, or otherwise does not necessarily constitute or imply its endorsement, recommendation, or favoring by the United States Government or any agency thereof. The views and opinions of authors expressed herein do not necessarily state or reflect those of the United States Government or any agency thereof. 


\section{DISCLAIMER}

Portions of this document may be illegible in electronic image products. Images are produced from the best available original document. 


\title{
GREENHOUSE-GAS EMISSIONS FROM BIOFUEL USE IN ASIA
}

\author{
David G. Streets and Stephanie T. Waldhoff \\ Decision and Information Sciences Division \\ Argonne National Laboratory \\ 9700 South Cass Avenue \\ Argonne, IL 60439, U.S.A.
}

\begin{abstract}
$\underline{\text { Abstract }}$
Biomass is a primary fuel for much of the world's population. In some developing countries it can contribute $80-90 \%$ of total primary energy consumption. In Asia as a whole we estimate that biomass contributes about $22 \mathrm{EJ}$, almost $24 \%$ of total energy use. Much of this biomass is combusted in inefficient domestic stoves and cookers, enhancing the formation of products of incomplete combustion (PIC), many of which are greenhouse gases. An inventory of the combustion of biofuels (fuelwood, crop residues, and dried animal waste) in Asia is used to develop estimates of the emissions of carbon-containing greenhouse gases $\left(\mathrm{CO}_{2}, \mathrm{CO}, \mathrm{CH}_{4}\right.$, and $\left.\mathrm{NMHC}\right)$ in Asian countries. The data are examined from two perspectives: total carbon released and total global warming potential (GWP) of the gases. We estimate that biofuels contributed $573 \mathrm{Tg}-\mathrm{C}$ in 1990 , about $28 \%$ of the total carbon emissions from energy use in Asia. China (259 Tg-C) and India (187 Tg-C) were the largest emitting countries by far. The majority of the emissions, $504 \mathrm{Tg}-\mathrm{C}$, are in the form of $\mathrm{CO}_{2}$; however, emissions of non- $\mathrm{CO}_{2}$ greenhouse gases are significant: $57 \mathrm{Tg}-\mathrm{C}$ as $\mathrm{CO}, 6.4 \mathrm{Tg}-\mathrm{C}$ as $\mathrm{CH}_{4}$, and $5.9 \mathrm{Tg}-\mathrm{C}$ as NMHC. Because of the high rate of incomplete combustion in typical biofuel stoves and the high GWP coefficients of the products of incomplete combustion, biofuels comprise an even larger share of energy-related emissions when measured in terms of global warming potential (in $\mathrm{CO}_{2}$ equivalents): $38 \%$ over a 20 -year time frame and $31 \%$ over 100 years. Even when the biofuel is assumed to be harvested on a completely sustainable basis (all $\mathrm{CO}_{2}$ emissions are reabsorbed in the following growing season), PIC emissions from biofuel combustion account for almost $5 \%$ of total carbon emissions and nearly $25 \%$ of $\mathrm{CO}_{2}$ equivalents in terms of short-term (20year) GWP.
\end{abstract}

\section{Introduction}

An inventory of biofuel use in Asia in 1990 is used to calculate greenhouse-gas emissions on a regional scale. The regions examined are East Asia, Southeast Asia, and the Indian Subcontinent. Four species of greenhouse gases are examined: carbon dioxide $\left(\mathrm{CO}_{2}\right)$, carbon monoxide $(\mathrm{CO})$, methane $\left(\mathrm{CH}_{4}\right)$, and nonmethane hydrocarbons (NMHC), with the last three being products of incomplete combustion (PIC). Three principal types of biofuels are evaluated: fuelwood, crop residues, and animal waste. Each type of fuel has its own unique emission pattern. It is found that significant variations in species contribution exist across regions, due primarily to the regional differences in biofuel consumption. In addition, it is found that the PIC contribute more to global warming on a carbon-weight basis than does $\mathrm{CO}_{2}$ and are emitted in especially high proportions in biofuel combustion. Because of this and the large quantities of biofuel used in Asia, it is important to include these PIC in any greenhouse-gas emissions inventory. Finally, the contribution of these 
gases in terms of global warming potential (GWP) are calculated and examined on a regional level.

Biomass is a primary fuel for much of the world's population; biomass can contribute as much as $80-90 \%$ of total primary energy consumption in some less-developed countries (Smith, 1987). Biomass burning is often assumed to be neutral with respect to carbon-containing greenhouse gases-that is, all the $\mathrm{CO}_{2}$ emitted in the burning process is assumed to be taken up in the following growing season by new crops and trees. However, only when the biofuel is harvested on a sustainable basis-a new tree planted for each tree cut down for fuelwood-and only when all the carbon in the fuel is completely combusted to form $\mathrm{CO}_{2}$ can this process be considered carbonneutral. While some countries are working towards sustainable harvesting, it is not the common practice in most of the developing world.

In addition, most biomass stoves in the developing world have low combustion efficiencies. Combustion efficiency is inversely related to the formation of products of incomplete combustion (PIC) (Smith et al, 1993). In other words, lower combustion efficiencies lead to higher PIC levels. The most important components of $\mathrm{PIC}$ are $\mathrm{CO}, \mathrm{CH}_{4}$, and $\mathrm{NMHC}$. On a carbon-weight basis, each of these three trace gases contributes more to global warming than does $\mathrm{CO}_{2}$. The concept of global warming potential was developed in order to compare heat-trapping abilities across species, relative to $\mathrm{CO}_{2}$. To do this, actual emissions are multiplied by a species-appropriate GWP-factor. The purpose of this paper is to examine the regional variations in greenhouse-gas emissions and GWP resulting from the use of different biofuels across three main regions in Asia.

\section{Methodology}

A 1990 inventory of biofuel combustion (Streets and Waldhoff, 1998) is combined with emission factors for the four greenhouse-gas species examined here. (See Streets and Waldhoff, 1999 for a review of the current literature on emission factors.) Species emission factors vary by fuel type; specifically, woody biofuels (fuelwood and crop residues) are known to have relatively higher $\mathrm{CO}$ emissions, while animal waste combustion releases relatively more $\mathrm{CH}_{4}$ and $\mathrm{NMHC}$. However, these emission factors are known to vary significantly when burning conditions are altered (Delmas et $a l$, 1995; Lobert et al, 1991; Crutzen and Andreae, 1990). Specifically, it has been observed that PIC formation increases as the flaming stage is reduced and the smoldering stage is increased. This is because the smoldering stage allows the least amount of mixing between oxygen and carbon, so a greater share of carbon is not completely combusted. Variations in burning conditions can result from differences in fuel type, stove design, wind speed, and many other factors. These variations make it difficult to determine average lengths of the flaming and smoldering stages, and therefore average emission factors. Data were examined to this end, and the emission factors that appeared to most accurately represent emissions under common burning conditions for $\mathrm{CO}_{2}, \mathrm{CO}, \mathrm{CH}_{4}$, and $\mathrm{NMHC}$ were chosen.

Emission factors were applied to the inventory of biofuel combustion, and emissions were calculated on a carbon-weight basis for each species $\left(1 \mathrm{~g}-\mathrm{C}\left(\mathrm{CO}_{2}\right)=12 / 44 \mathrm{~g}-\mathrm{CO}_{2}\right)$ and in terms of both 20-year and 100-year global warming potentials. Estimates of the global warming potentials of each trace gas (Table 1) were gathered (Smith et al, 1993; IPCC, 1997) and combined with the emission estimates to approximate the impact on global warming in $\mathrm{CO}_{2}$ equivalents (Table 2). Because trace gases (PIC) tend to have large heat-trapping capabilities, but relatively short atmospheric life times, the impacts of trace gases on global warming are highly dependent on the time-frame chosen. For this reason, trace gases were examined using three measures: absolute carbon emissions, short term GWP (20 years), and long term GWP (100 years). 
Table 1. Global warming potentials*, 20-year and 100-year time frames.

\begin{tabular}{|l|c|c|c|c|}
\hline & $\mathrm{CO}_{\mathbf{2}}$ & $\mathbf{C O}$ & $\mathrm{CH}_{\mathbf{4}}$ & NMHC \\
\hline 20 -year & 1.0 & 4.5 & 22.0 & 12.0 \\
\hline 100-year & 1.0 & 1.9 & 7.5 & 4.1 \\
\hline
\end{tabular}

*Calculated on a carbon-weight basis.

(Source: Smith et al, 1993)

The GWP of methane has been well established (Smith et al, 1993; IPCC, 1996; EPA, 1999), but the GWP of $\mathrm{CO}$ and NMHC are less certain. Both $\mathrm{CO}$ and $\mathrm{NMHC}$ are believed to have negligible direct radiative forcing effects (IPCC, 1992). However, they do have significant indirect effects, due to their involvement in chemical reactions in the troposphere that influence the formation of $\mathrm{O}_{3}$ and $\mathrm{OH}$ radicals (IPCC, 1992). And, of course, their ultimate fate is conversion to $\mathrm{CO}_{2}$. The net indirect effects of $\mathrm{CO}$ and NMHC are believed to be positive, i.e., they contribute to global warming, rather than cooling, but the values of their GWP are uncertain. The values used by Smith et al (1993) are based on 1990 IPCC estimates (IPCC, 1990). Subsequent IPCC reports $(1992,1996)$ have not included estimates of the GWP of CO and NMHC, because IPCC scientists "...are now aware of additional complications affecting such calculations and are less sure of the results" (IPCC, 1996, p. 62). It is concluded that " $\mathrm{CO}$ and $\mathrm{NMHC}$ will...make positive indirect contributions, although they are believed to be less significant than the contribution from $\mathrm{CH}_{4}$ and more difficult to assess due to temporal and spatial variations in concentration" (IPCC, 1992 p. 61). In the absence of better information, we use the original 1990 IPCC values for the GWP of CO and NMHC, as interpreted by Smith et al (1993).

Country-level data were then aggregated to a geographic regional level. These regions are East Asia, including mainland China, Taiwan, Hong Kong, Japan, North and South Korea, and Mongolia; Southeast Asia, including Indonesia, Malaysia, Philippines, Singapore, Brunei, Myanmar, Thailand, Vietnam, Laos, and Cambodia; and the Indian Subcontinent, including India, Pakistan, Bangladesh, Nepal, Bhutan, and Sri Lanka. These three regions were chosen because of geographic proximity and because of similar fuel-usage patterns in neighboring countries. For instance, countries in the region of East Asia tend to use primarily crop residues and fuelwood for their biofuel needs, while countries in the Indian Subcontinent also use a large amount of animal waste as fuel. The main exception to these similarities is Mongolia, which is included in East Asia because of geographic location, but which uses large amounts of animal waste as fuel, similar to countries in the Indian Subcontinent region.

$\underline{\text { Results }}$

Total carbon emissions from biofuel combustion in Asia are $572.9 \mathrm{Tg}-\mathrm{C}$ (Table 2). Emissions are given in teragrams $\left(10^{12} \mathrm{~g}\right)$ of carbon equivalent $[\mathrm{Tg}-\mathrm{C}]$; note that $1 \mathrm{Tg}-\mathrm{C}$ of $\mathrm{CO}_{2}$ is equal to $12 / 44 \mathrm{Tg}-\mathrm{CO}_{2}$. Emissions in the East Asia and Indian Subcontinent regions are dominated by the world's two most populous countries: China (258.8 Tg-C) and India (187.0 Tg-C). China and India together contributed over $75 \%$ of all the carbon emissions from biofuel combustion in Asia.

The majority of carbon emissions, $503.9 \mathrm{Tg}-\mathrm{C}$, were in the form of $\mathrm{CO}_{2}$. However, $56.7 \mathrm{Tg}$ - 
$\mathrm{C}$ were emitted as $\mathrm{CO}, 6.4 \mathrm{Tg}-\mathrm{C}$ as $\mathrm{CH}_{4}$, and $5.9 \mathrm{Tg}-\mathrm{C}$ as $\mathrm{NMHC}$. Percentages varied by region, with the Indian Subcontinent with its large amounts of animal waste combustion having proportions of $\mathrm{CH}_{4}$ and $\mathrm{NMHC}$ roughly $50 \%$ higher than East and Southeast Asia, where primary biofuel combustion is in the form of fuelwood and crop residues.

Table 2. Regional Emissions of Greenhouse Gases from Biofuel Combustion in Asia - 1990

\begin{tabular}{|c|c|c|c|c|c|c|c|c|c|c|}
\hline & \multicolumn{5}{|c|}{ Total Carbon Emissions (Tg-C) } & & & & & \\
\hline Region & $\mathrm{CO}_{2}$ & $\mathbf{C O}$ & $\mathrm{CH}_{4}$ & NMHC & Total & & & & & \\
\hline East Asia & 237.6 & 27.5 & 2.6 & 2.1 & 269.8 & & & & & \\
\hline $\begin{array}{l}\text { of which } \\
\text { China* }\end{array}$ & 227.9 & 26.5 & 2.5 & 2.0 & 258.8 & & & & & \\
\hline 必 & & & & & ख. & & & & & \\
\hline $\begin{array}{l}\text { Indian } \\
\text { Subcon- } \\
\text { tinent }\end{array}$ & 199.4 & 22.1 & 3.2 & 3.2 & 227.8 & & & & & \\
\hline $\begin{array}{l}\text { of which } \\
\text { India }\end{array}$ & 163.6 & 18.0 & 2.7 & 2.7 & 187.0 & & & & & \\
\hline$x_{2}$ & & & ( & खा & 직 & & & & & \\
\hline $\begin{array}{l}\text { Southeast } \\
\text { Asia }\end{array}$ & 67.0 & 7.1 & 0.7 & 0.6 & 75.3 & & & & & \\
\hline Total Asia & 503.9 & 56.7 & 6.4 & 5.9 & 572.9 & & & & & , \\
\hline & 20-yea & $\overline{\text { GWP }(\mathrm{Tg}}$ & arbon (C & $\left.\mathrm{O}_{2}\right)$ Equival & ents) & 100-yea & $\overline{\text { GWP }(\mathrm{Tg}}$ & Carbon (C & $\mathrm{O}_{2}$ ) Equiva & ents) \\
\hline Region & $\mathrm{CO}_{2}$ & $\mathbf{C O}$ & $\mathrm{CH}_{4}$ & NMHC & Total & $\mathrm{CO}_{2}$ & $\mathrm{CO}$ & $\mathbf{C H}_{4}$ & NMHC & Total \\
\hline \begin{tabular}{|l|} 
East Asia \\
\end{tabular} & 237.6 & 123.9 & 57.2 & 24.7 & 443.4 & 237.6 & 52.3 & 19.5 & 8.4 & 317.9 \\
\hline $\begin{array}{l}\text { of which } \\
\text { China* }\end{array}$ & 227.9 & 119.1 & 55.0 & 23.7 & 425.7 & 227.9 & 50.3 & 18.7 & 8.1 & 305.0 \\
\hline \begin{tabular}{|l} 
Indian \\
Subcon- \\
tinent
\end{tabular} & 199.4 & $\frac{.}{99.2}$ & 70.3 & 38.9 & 407.7 & 199.4 & 41.9 & 24.0 & 13.3 & 278.5 \\
\hline \begin{tabular}{|l|} 
of which \\
India
\end{tabular} & 163.6 & 81.2 & 58.4 & 32.5 & 335.7 & 163.6 & 34.3 & 19.9 & 11.1 & 228.9 \\
\hline & & 展 & 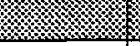 & স্য & . & . & & (1: & 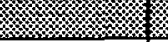 & אy \\
\hline \begin{tabular}{|l} 
Southeast \\
Asia
\end{tabular} & 67.0 & 31.8 & 14.3 & 6.9 & 120.0 & 67.0 & 13.4 & 4.9 & 2.3 & 87.6 \\
\hline & & X & & 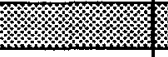 & & 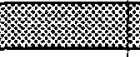 & & ঋেশ & : & 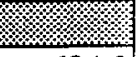 \\
\hline Total Asia & 503.9 & 255.0 & 141.8 & 70.4 & 971.1 & 503.9 & 107.7 & 48.3 & 24.1 & 684.0 \\
\hline
\end{tabular}

* Not including Taiwan and Hong Kong

When emissions of the trace gases are multiplied by their GWP coefficients, the effects on global warming of $\mathrm{CO}, \mathrm{CH}_{4}$, and NMHC become more evident (Fig. 1). In terms of GWP, PIC play a much larger role, per carbon atom, than $\mathrm{CO}_{2}$. When examined in terms of total carbon emissions, East Asia, Southeast Asia, and the Indian Subcontinent emit 269.8, 75.3, and 227.8 mt-C, respectively (Table 2). When these figures are interpreted in terms of 20-year GWP, however, they become $443.4,120.0$, and $407.7 \mathrm{mt}-\mathrm{CE}$ (carbon equivalents), respectively. The increases are $64.3 \%$, 
$59.4 \%$, and $79.0 \%$ for the three regions. Because combustion of animal waste produces more $\mathrm{CH}_{4}$ and NMHC, which have higher GWP factors (Table 1), regions that burn large amounts of animal waste will contribute more to global warming than suggested by their absolute carbon emissions. This is exemplified by these percent increases. East Asia and Southeast Asia show similar increases, as expected, due to the similar composition of their biofuel combustion (East Asia, which includes Mongolia, has a slightly higher increase due to the large amount of animal waste burned there). The Indian Subcontinent has a significantly higher increase between total carbon emissions and the 20-year GWP, due to the important role of animal waste as a fuel in this region.

Fgare 1 Pencent Greenhouse Cas Emissions trom Biofuel Combustion in Asia by Region and Species: Total Carbon, 20-year, and 100-year GWP

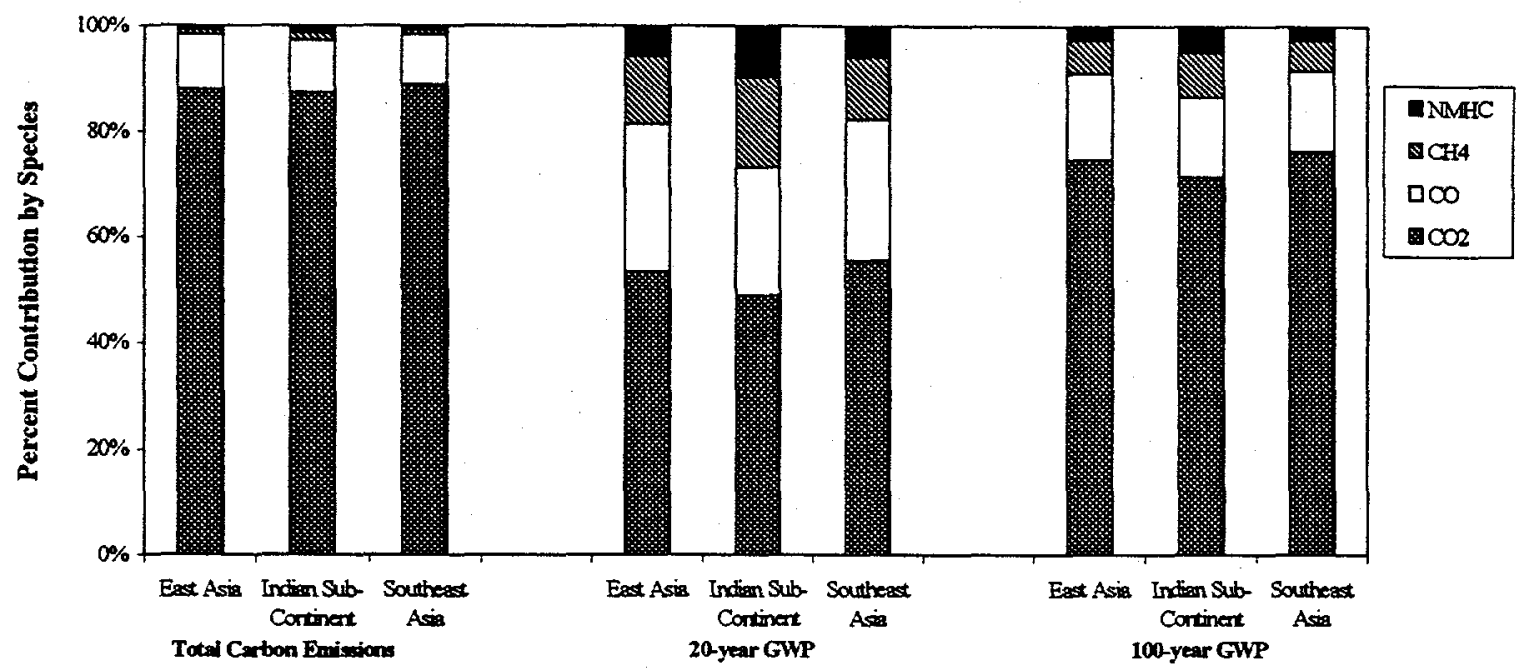

Biofuels are often regarded as greenhouse-gas neutral, that is, all $\mathrm{CO}_{2}$ emissions released in the burning process are assumed to be reabsorbed by new plant growth in the following growing season. Although this is an over-simplification, we will assume here that when harvested sustainably (for each tree burned, a new one is planted), all $\mathrm{CO}_{2}$ is reabsorbed in the following season. We know that biomass stoves have low combustion efficiencies and therefore not all the carbon stored in the biofuel is completely combusted to $\mathrm{CO}_{2}$ (Smith et al, 1993). In 1990, 12\% of the carbon emissions from biofuels consumed in Asia were released as PIC $(69.0 \mathrm{mt}-\mathrm{C})$. When the PIC were converted to $\mathrm{CO}_{2}$ equivalents on a 20 -year scale they contributed $48 \%$ of the $\mathrm{CO}_{2}$ equivalent from biofuel consumption. Although this percent decreases over the longer term (100-year) scale, the $\mathrm{CO}_{2}$ equivalent from $\mathrm{CO}, \mathrm{CH}_{4}$, and NMHC is still estimated to contribute $26 \%$ of the total $\mathrm{CO}_{2}$ equivalent from biofuel consumption (Fig. 1). Obviously, PIC play a significant role in the GWP from biofuel combustion.

Relative to fossil fuel emissions, biofuels contribute a significant amount to the total GWP. If we assume that all $\mathrm{CO}_{2}$ from biofuel combustion is reabsorbed, then we need only examine the contribution of the PIC relative to total (including fossil fuel) emissions. In 1990, total carbon emissions from fossil fuel combustion in Asia were 1,476.8 mt-C (Streets and Waldhoff, 1999). PIC emissions from biofuel combustion, at $69.0 \mathrm{mt}-\mathrm{C}$, were nearly $5 \%$ of total carbon emissions in Asia in 1990 (not including $\mathrm{CO}_{2}$ from biofuel that may be reabsorbed). However, when this exercise is repeated for 20 -year and 100 -year GWP, this figure increases to $22.7 \%$ and $10.7 \%$, respectively. 
This means that over the next 20 years, PIC emissions from biofuel combustion are expected to account for nearly $25 \%$ of the GWP in Asia. Biofuel combustion is clearly not greenhouse-gas neutral.

Many attempts have been made to increase the efficiency of heat transfer in biofuel stoves (and therefore to reduce the demand for biofuels). One method for accomplishing this is to limit the air supply to the fuel. Unfortunately, we know that decreasing air supply will increase the smoldering time of the fuel, thereby increasing PIC production (Smith et al, 1993, Lobert et al, 1991). The negative greenhouse gas, health, and energy effects of increased PIC production make it very important that heat transfer efficiency in biofuel stoves is not increased at the expense of combustion efficiency.

\section{Health Effects}

There are two other important reasons for improving combustion efficiency in typical biofuel stoves. The first is the negative health effects associated with high concentrations of PIC found in homes using biofuel stoves. The potentially deadly effects of $\mathrm{CO}$ are well known, to the extent that many American households now have $\mathrm{CO}$ detectors to warn of high levels of this poisonous gas. Other PIC, especially inhaled particulates, are also very dangerous to human health. “...[H]uman particulate exposures from biomass use could be responsible for something more than one-half of the total global exposure." (Smith et al, 1993) These PIC also contribute to the development of pneumonia in children living in developing countries.

Not only do PIC represent very real health risks to the women and children consistently exposed to them, they also signify low energy efficiency. Incomplete combustion represents lost energy and heat, increasing the amount of fuel required to cook a meal or heat a home (Smith $\mathrm{et} \mathrm{al}$, 1993). In fact, Smith states that the results of his pilot study in Manila indicate that "...the loss of energy represented by the PIC from biomass-fired cookstoves is roughly $1 \%$ of the total human energy use and could approach $10 \%$ for some [developing] countries." (Smith et al, 1993)

\section{Conclusions}

These data show the assumption that biofuel combustion is neutral in terms of global warming to be erroneous. It is also clear that examination of all products of combustion, not just $\mathrm{CO}_{2}$, is important in fully understanding the effects of this type of fuel combustion. Because different biofuels release PIC in varying amounts, and because these PIC have significantly different GWP, understanding the problem of regional greenhouse-gas emissions must include a careful analysis of all types of biofuel combustion. Under current conditions (the prevalence of biofuel stoves with low combustion efficiencies and the consistent unsustainable harvesting of fuels), biofuel combustion most definitely contributes to global warming and has other effects. There are remedies to this problem. Most obviously, the use of stoves with higher combustion efficiencies should be increased and more biofuel should be sustainably harvested. In time, and with appropriate policies, domestic biofuel combustion will be replaced entirely by cleaner fuels (such as natural gas or electricity) and any biomass-to-energy processes will use larger, more sophisticated techniques (such as gasification). Recognizing the significance of biofuel combustion to greenhouse-gas emissions will aid in the development of appropriate and feasible solutions to the energy needs of Asia.

\section{Acknowledgments}

This work was partially supported by the U.S. Department of Energy under contract W-31- 
109-Eng-38 and partially by the National Aeronautics and Space Administration under Interagency Agreement S-92591-F with the U.S. Department of Energy. The opinions expressed herein are those of the authors themselves and should not be construed as representing the official positions of Argonne National Laboratory, the U.S. Department of Energy, or the National Aeronautics and Space Administration.

\section{References}

Crutzen, P.J. and Andreae, M.O., Science, 1990, 250, 1669-1678.

Delmas, R., LaCaux, J.P., and Brocard, D., Environmental Monitoring and Assessment, $1995,38,181-204$.

EPA, 1999, http://www.epa.gov/oppeoeel/globalwarming/inventory/1998-inv/gwp.html.

IPCC. Climate change: the IPCC scientific assessment. Cambridge UK: Cambridge University Press, 1990.

IPCC Working Group I. Climate Change 1992: the supplementary report to the IPCC scientific assessment. Cambridge UK: Cambridge University Press, 1992.

IPCC Working Group I. Climate Change 1995: the science of climate change. Cambridge UK: Cambridge University Press, 1996.

IPCC Working Group, "Greenhouse Gas Inventory Workbook, Vol. 2" Intergovernmental Panel on Climate Change, Bracknell, UK, 1997.

Lobert, J.M., Scharffe, D.H., Hao, W.M., Kuhlbusch, T.A., Seuwen, R., Warneck, P., Crutzen, P.J., In Levine J.S., editor, "Global Biomass Burning” Cambridge MA: MIT Press, 1991, p. 289-304.

Smith, Kirk R., "Biofuels, Air Pollution, and Health" Plenum Press, New York, 1987.

Smith, K.R., Khalil, M.A.K., Rasmussen, R.A., Thorneloe, S.A., Manegdeg, F., Apte, M., Greenhouse gases from biomass and fossil fuel stoves in developing countries: a Manila pilot study. Chemosphere 1993, 26, 479-505.

Streets, D.G. and Waldhoff, S.T., Energy-The International Journal, 1998, 23, 1029-1042.

Streets, D.G. and Waldhoff, S.T., Energy-The International Journal, 1999, in press. 